\title{
Analisis Hambatan Komunikasi Guru dan Siswa dalam Pembelajaran IPA di SMP Negeri Kecamatan Moyo Hulu
}

\author{
Indah Dwi Lestari \\ Pendidikan Biologi FKIP Universitas Samawa \\ Email: indahlestari656@gmail.com
}

\section{Article Info \\ Article History \\ Received: 2020-11-17 \\ Revised: 2021-01-05 \\ Published: 2021-01-18}

\section{Keywords:}

Communication Barriers;

Teachers and Students;

Science Learning.

\begin{abstract}
This study aims to determine the communication barriers between teachers and students in science learning at SMP Negeri Moyo Hulu District and to find out the impact of communication barriers between teachers and students in science learning and to determine the efforts made by teachers and students so as not to experience obstacles in learning science. The method in this research is descriptive qualitative. The subjects in this study were science teachers and students at SMP Negeri Moyo Hulu District. The sample taken consisted of 5 science teachers and 25 students. Sampling using purposive sumpling method. Data collection techniques using interviews, questionnaires (questionnaire). Data validity test and triangulation. The results of the research from the 5 indicators that have been carried out are that there are communication barriers between teachers and students in science learning. This can be seen from students who do not master Latin, have difficulty understanding the material, lack self-confidence, who often skip classes and students feel lazy so that it will affect communication between teachers and students in science learning. The impact of teacher and student communication barriers was caused by students whose methods the teacher applied were unable to make innovative and creative learning so that students became lazy to learn, students who did not like material containing Latin and a lot of science material so that students had difficulty understanding the material. The effort made by the teacher is to encourage, motivate and increase students' selfconfidence by taking an individual approach.
\end{abstract}

\begin{tabular}{l}
\hline Artikel Info \\
\hline Sejarah Artikel \\
Diterima: $2020-11-17$ \\
Direvisi: 2021-01-05 \\
Dipublikasi: 2021-01-18
\end{tabular}

Kata kunci: Hambatan Komunikasi; Guru dan Siswa; Pembelajaran IPA.

\begin{abstract}
Abstrak
Penelitian ini bertujuan untuk mengetahui hambatan komunikasi guru dan siswa dalam pembelajaran IPA di SMP Negeri Kecamatan Moyo Hulu dan mengetahui dampak adanya hambatan komunikasi antara guru dan siswa dalam pembelajaran IPA serta mengetahui upaya yang dilakukan guru dan siswa agar tidak mengalami hambatan dalam pembelajaran IPA. Metode dalam penelitian ini adalah Deskriptif Kualitatif. Subjek dalam penelitian ini adalah guru IPA dan peserta didik di SMP Negeri Kecamatan Moyo Hulu. Sampel yang diambil terdiri dari 5 guru IPA dan 25 peserta didik. Pengambilan sampel dengan menggunakan metode purposive sumpling. Teknik pengumpulan data menggunakan wawancara, angket (kuesioner). Uji keabsahan data dan triangulasi. Hasil penelitian dari 5 indikator yang telah dilakukan adalah terdapat adanya hambatan komunikasi guru dan siswa dalam pembelajaran IPA. Hal ini dilihat dari siswa yang kurang menguasai bahasa latin, kurang logis dalam bertanya, sulit memahami materi, siswa kurang percaya diri dalam bertanya serta rasa malas siswa sehingga akan mempengaruhi komunikasi antara guru dan siswa dalam pembelajaran IPA. Dampak adanya hambatan komunikasi guru dan siswa diakibatkan oleh siswa yang metode yang diterapkan guru tidak mampu membuat pembelajaran inovatif dan kreatif sehingga siswa menjadi malas belajar, siswa yang kurang suka materi yang mengandung bahasa latin dan materi IPA yang banyak sehingga siswa jadi sulit memahami materi. Upaya yang dilakukan guru adalah menyemangati memotivasi dan meningkatkan rasa percaya diri siswa dengan melakukan pendekatan individual.
\end{abstract}

\section{PENDAHULUAN}

Pemerintah dan penyelenggara pendidikan melakukan perbaikan mutu pendidikan secara terusmenerus. Hal ini diperlukan adanya upaya untuk meningkatkan kualitas pendidikan, khususnya dimulai dari guru, karena guru sebagai pendidik dibarisan terdepan yang tugas dan fungsinya berhubungan langsung dengan siswa, guru mempunyai tugas utama dalam pembelajaran di sekolah untuk menciptakan suasana belajar yang 
menyenangkan sehingga berdampak positif dalam pencapaian prestasi belajar siswa (Abdul, 2014: 201). Pembelajaran merupakan suatu sistem, yang terdiri atas berbagai komponen yang saling berhubungan satu dengan yang lain. Komponen tersebut meliputi: Tujuan, materi, metode, dan evaluasi. Keempat komponen pembelajaran tersebut harus diperhatikan oleh guru dalam memilih dan menentukan modelmodel pembelajaran apa yang akan digunakan dalam kegiatan pembelajaran (Rusman, 2012: 1).

Pembelajaran adalah proses interaksi siswa dengan pendidik dan sumber belajar pada suatu lingkungan belajar. Pembelajaran merupakan bantuan yang diberikan pendidik agar dapat terjadi proses memperoleh ilmu dan pengetahuan, penguasaan kecakapan, pembentukan sikap dan kepribadian peserta didik (Hardianto, 2012: 5-6). Pembelajaran merupakan peristiwa sehari-hari di sekolah. Belajar merupakan hal yang kompleks. Kompleksitas belajar tersebut dapat dipandang dari dua subjek, yaitu siswa dan dari guru (Dimyati dan Mudjiono, 2013: 17). Berkaitan dengan kinerja guru, wujud perilaku yang dimaksud adalah kegiatan guru dalam proses pembelajaran, yaitu bagaimana seorang guru merencanakan pembelajaran, melaksanakan kegiatan pembelajran, dan menilai hasil belajar (Rusman, 2012: 50).

Pada hakekatnya komunikasi merupakan proses penyampaian pikiran atau gagasan serta perasaan oleh seseorang (komunikator) kepada orang lain (komunikan). Pikiran bias atau berprasangka berupa gagasan, informasi, opini, dan lain-lain yang muncul di benaknya. Perasaan berupa keyakinan, kepastian, keragu- raguan, kekhawatiran, kemarahan, keberanian dan sebagainya (Dirman, 2014:14). Pengajaran pada dasarnya merupakan suatu proses terjadinya interaksi antara guru dengan siswa melalui kegiatan terpadu dari dua bentuk kegiatan, yakni kegiatan belajar siswa dengan kegiatan belajar dengan guru. Untuk mencapai interaksi belajar mengajar tentu adanya komunikasi yang jelas antara guru (pengajar) dengan siswa (pelajar) sehingga terpadunya dua kegiatan yakni kegiatan mengajar (usaha guru) dengan kegiatan belajar (tugas siswa) yang berdaya guna dalam mencapai pengajaran (Sudjana, 2015: 28). Dalam proses pendidikan sering kita jumpai kegagalan maupun hambatan yang muncul, hal ini dikarenakan lemahnya sistem komunikasi diantara kedua pihak akibat faktor perbedaan budaya antara guru dan murid tersebut, dan juga terkadang guru (komunikator) tidak dapat menyampaikan pesannya dengan sukses karena siswa (komunikan) sulit memahami apa yang disampaikan guru. Hambatan komunikasi adalah segala sesuatu yang menghalangi atau mengganggu tercapainya komunikasi yang baik dan juga komunikasi yang efektif. Hambatan komunikasi merupakan segala sesuatu yang dapat mendistorsi pesan atau menghalangi pesan, hal apapun yang menghalangi penerima dalam menerima pesan,
Timotius (Vito, 2015:11-14).

Faktor komunikasi itu sangat mendukung dalam proses perkembangan proses pelajaran baik di dalam ruangan kelas maupun di lingkungan sekolah, dengan adanya komunikasi yang baik dan efektif maka akan menimbulkan hasil yang positif. Komunikasi yang baik antara guru dan siswa maka akan tercapainya proses belajar mengajar yang efektif, dengan demikian diperlukan konsepsi pola komunikasi antara guru dan siswa agar terwujud proses belajar mengajar yang efektif.

Pendidikan merupakan salah satu bentuk pembangunan nasional yaitu menciptakan manusia berkualitas. Melalui pendidikan manusia dapat mengaktualisasikan semua potensi yang dimiliki. Siswa Sekolah Menengah Atas memasuki fase remaja dewasa, fase ini merupakan periode dalam kehidupan manusia yang batasan usia maupun perannya seringkali tidak terlalu jelas. Hal ini menunjukan bahwa siswa SMP perlu diberikan bekal sehingga dapat berkembang menjadi lebih baik. Melalui pendidikan di sekolah yang merupakan proses pengembangan berbagai kemampuan dan sikap.

Salah satu kemampuan yang harus dikembangkan adalah kemampuan komunikasi interpersonal. Hal ini merupakan aspek terpenting dalam kehidupan karena setiap orang tidak lepas dari kegiatan komunikasi dan interaksi dengan orang lain. Siswa yang merasa sulit berkomunikasi dengan orang lain lebih banyak berprilaku negatif. Ia akan menjadi agresif, senang berkhayal, dingin, sakit fisik dan mental, dan menderita, 'flight syindrome" atau melarikan diri dari lingkungannyaKemampuan berkomunikasi sangatlah penting bagi siswa karena dalam proses pembelajaran siswa dituntut untuk mengeluarkan pendapatnya masing-masing. Cara yang sering digunakan guru adalah dengan meminta siswa untuk berbicara di depan kelas, bertanya dan menjawab pertanyaan-pertanyaan dari guru.

Hasil wawancara yang dilakukan dengan guru IPA yang ada di SMPN Kecamatan Moyo Hulu bahwa ada beberapa permasalahan yang ditemukan terkait komunikasi guru dan siswa dalam pembelajaran IPA yaitu siswa sulit memahami materi, kurangnya ketersediaan alat dan bahan untuk praktikum pada mata pelajaran IPA, kurangnya keaktifan siswa dalam berkomunikasi selama proses pembelajaran, siswa yang masih malu mengeluarkan pendapat, motivasi siswa rendah dan siswa yang bolos. Hal tersebut tentunya akan berdampak pada interaksi guru dan siswa dalam pembelajaran IPA.

\section{METODE PENELITIAN}

Metodologi adalah proses, prinsip dan prosedur yang gunakan untuk mendekati problem dan mencari jawaban. Metodologi dipengaruhi atau berdasarkan perspektif teoritis yang gunakan untuk melakukan penelitian, sementara perspektif teoritis itu sendiri adalah penjelasan atau interpretasi yang memungkinkan peneliti memahami data dan 
menghubungkan data yang rumit dengan peristiwa dan situasi lain

Penelitian ini menggunakan Metode deskriptif kualitatif, yaitu metode penelitian yang digunakan untuk meneliti pada kondisi obyek yang alamiah, dimana peneliti adalah sebagai instrumen kunci. Metode kualitatif digunakan untuk mendapat data mendalam atau mengandung makna yang sebenarnya, data yang pasti dibalik data yang tampak apa adannya dan tidak di manipulasi (Sugiyono, 2016:8). Subjek adalah guru IPA, siswa kelas VII dan siswa kelas IX di SMPN di Kecamatan Moyo Hulu. Instrumen yang digunakan adalah wawancara dan angket, mengambil 5 sample guru dari 5 SMP, sedangkan untuk siswa, mengambil 5 sample di masing masing sekolah yang ada di Kecamatan Moyo Hulu. Jadi total siswa yang di berikan angket berjumlah 25 siswa menggunakan metode purposive sampling dimana data pengambilan sample secara sengaja sesuai dengan persyaratan sample yang diperlukan. Instrumen yang digunakan untuk pengumpulan data adalah wawancara untuk guru, angket guru dan angket siswa dengan jumlah pertanyaan wawancara 17 soal sedangkan untuk angket guru dan siswa masingmasing berjumlah 15 soal.

\section{HASIL DAN PEMBAHASAN}

Instrumen yang digunakan untuk pengumpulan data yaitu pedoman wawancara, angket guru dan angket siswa berdasarkan 5 indikator yang dilakukan di SMPN Kecamatan Moyo Hulu yaitu kejelasan, ketepatan, konteks, alur dan budaya. Adapun data yang diperoleh dalam penelitian ini yaitu:

a) Kejelasan

Dari hasil wawancara, dan hasil angket guru bahwa guru IPA yang ada di SMP Negeri Kecamatan Moyo Hulu telah memberikan kejelasan kepada peserta didik. Hal ini dilihat dari sangat berpengaruhnya komunikasi terhadap proses KBM dengan melihat kemampuan bertanya siswa serta guru yang meningkatkan rasa percaya diri siswa dengan melakukan pendekatan individualisme kepada siswa atau peserta didik. Selain itu, guru juga menyampaikan materi dengan jelas kepada siswa sehingga siswa dapat memahami materi dengan sangat mudah. Hal tersebut dikuatkan oleh hasil angket peserta didik bahwa guru selalu menggunakan intonasi yang jelas dalam KBM, jika guru menggunakan intonasi yang jelas maka siswa akan mendapatkan materi dengan jelas.

b) Ketepatan

Dari hasil wawancara guru dan hasil angket guru di SMPN Negeri Kecamatan Moyo Hulu telah memberikan ketepatan kepada siswa dengan selalu berusaha menerapkan metode yang mampu mengaktifkan siswa, yaitu dengan menerapkan metode tanya jawab, metode kelompok dan metode praktikum, hal ini juga dikuatkan oleh hasil peserta didik bahwa metode yang digunakan oleh guru untuk mengaktifkan siswa adalah metode tanya jawab dan metode praktikum.

c) Konteks

Dari hasil wawancara guru dan hasil angket guru bahwa guru yang ada di SMPN Kecamatan Moyo Hulu telah memberikan konteks kepada siswa. Dengan mengaitkan materi dengan keadaan lingkungan sehari- hari siswa. selain itu guru selalu mengupayakan agar komunikasi yang siswa alami tidak mengalami hambatan. Hal ini juga dikuatkan oleh hasil angket peserta didik bahwa guru selalu mengaitkan materi dengan lingkungan sehari-hari siswa. Akan tetapi, pada indikator konteks terdapat adanya hambatan komunikasi guru dan siswa dalam pembelajaran IPA di SMPN Kecamatan Moyo Hulu yaitu siswa yang kurang suka materi yang mengandung bahasa latin, materi IPA yang banyak sehingga siswa sulit memahami materi serta kurangnya pengetahuan terhadap materi, selain itu siswa yang mempunyai rasa kurang percaya diri, ketika siswa disuruh bertanya siswa masih malu sehingga akan mempengaruhi interaksi komunikasi yang terjadi antara guru dan siswa.

d) Alur

Faktor-faktor yang terjadi terdapat adanya hambatan komunikasi yang dialami guru dan siswa dalam pembelajaran IPA yaitu siswa yang kurang suka materi yang mengandung bahasa latin, materi IPA yang banyak sehingga siswa sulit memahami materi serta kurangnya pengetahuan terhadap materi, Hal ini dikuatkan oleh hasil angket guru dan hasil angket siswa yaitu terkait hasil angket guru apakah siswa mendapatkan materi yang disusun secara sistematis sehingga siswa cepat tanggap, ini membuktikan bahwa guru selalu memberikan materi secara sistematis kepada siswa dan siswa selalu mendapatkan materi yang disusun secara sistematis sehingga siswa cepat tanggap. Selain itu guru juga memberikan solusi terkait hambatan yang terjadi dengan cara memberikan motivasi serta menyemangati dan memberikan aplaus /tepuk tangan kepada siswa siswa agar siswa lebih aktif dalam KBM.

e) Budaya

Dari hasil wawancara guru dan hasil angket guru dan siswa bahwa guru yang ada di SMPN Kecamatan Moyo Hulu telah menyesuaikan budaya yang dimiliki oleh siswa dengan kondisi yang ada dilingkungan sekolah yaitu dengan berusaha agar siswa selalu menggunakan bahasa indonesia dan guru selalu melakukan pendekatan individual kepada siswa jika ada siswa yang kurang dalam pendengaran sehingga akan menghambat komunikasi antara guru dan siswa, 
selain itu guru dan siswa selalu menggunakan bahasa yang sopan dalam KBM.

\section{SIMPULAN DAN SARAN}

\section{A. Simpulan}

Berdasarkan Hasil penelitian yang dilakukan, maka disimpulkan beberapa hal Berikut ini:

a) Siswa yang kurang suka materi yang banyak mengandung bahasa latin, materi IPA yang banyak sehingga siswa jadi sulit memahami materi, siswa yang kurang logis dalam mengemukakan pendapat, siswa yang kurang percaya diri dalam bertanya, siswa yang sering bolos dan timbulnya rasa malas siswa sehingga akan mempengaruhi komunikasi siswa pada mata mata pelajaran IPA.

b) Dampak adanya hambatan komunikasi guru dan siswa dalam pembelajaran IPA yaitu metode yang diterapkan oleh guru tidak mampu mengaktifkan siswa sehingga siswa jadi malas belajar selain itu siswa yang kurang suka dengan materi yang berhubungan dengan bahasa latin dan materi IPA yang cukup banyak sehingga siswa sulit memahami materi serta cara penyampaian guru terhadap materi tidak membuat siswa paham sehingga materi jadi tidak teratasi.

c) Upaya/Solusi yang dilakukan guru agar komunikasi guru dan siswa tidak mengalami hambatan yaitu dengan berusaha menyemangati siswa dengan selalu kasih aplaus/tepuk tangan ketika menjawab pertanyaan, dan diberikan motivasi kepada siswa agar siswa mau termotivasi dalam belajar terutama mata pelajaran IPA serta guru melakukan pendekatan individual agar rasa percaya diri siswa meningkat.

\section{B. Saran}

Saran yang disampaikan dalam penelitian ini diantaranya, bagi institusi, maupun peneliti dimasa yang akan datang agar dapat memperhatikan komunikasi diantara pendidik dan peserta didik sangatlah berpengaruh terhadap hasil belajar siswa, antara lain:

1. Bagi sekolah, disebabkan karena Adanya peningkatan hubungan antara siswa dan guru, disarankan agar memperlancar jalannya komunikasi yang baik dan efektif.

2. Guru diharapkan bersikp objektif dan terbuka pada semua siswa, agar siswa tidak merasa memperoleh perlakuan yang berbeda satu sama lainnya.

3. Bagi peneliti yang lain dapat menggembangkan penelitian tentang hambatan komunikasi dibidang kajian lainnya, karena masih banyak ruang untuk mengkaji penelitian hambatan komunikasi

\section{DAFTAR RUJUKAN}

Dirman \& Cicich. (2014). Penilaian Dan Evaluasi. Jakarta: Rineka Cipta.

Effendi \& Onong Uchjana. (2018). Ilmu Komunikasi (Teori Dan Praktek). Bandung: Remaja Rosdakarya.

Febriyana,M.,Marni, S \& Ferdi,S.R. (2015). Desain pembelajaran IPA terpadu pada siswa.

Moleong, L. (2014). Metodologi Penelitian Kualitatif (Rev. Ed). Bandung: PT Remaja Rosdakarya.

Sudjana, Nana.(2015). Penilaian Hasil proses Belajar Mengajar. Bandung: PT Remaja Rosdakarma.

Sugiyono. (2015). Metode Penelitian Bisnis. Bandung: Pusat Bahasa Depdiknas.

Sugiyono. (2016). Metode Penelitian Pendidikan (Pendekatan Kualitatif, dan Kuantitatif.)

Abdul, I. S. 2014. Profesionalisme Guru dalam Mengimplementasikan Teknologi Informasi dan Komunikasi di Kabupaten Nganjuk. Jurnal Pendidikan dan Kebudayaan 20(2): 200- 210.

Rusman. 2012. Model-model Pembelajaran. Jakarta: PT Raja Grafindo Persada.

Hardianto. 2012. Belajar dan Pembelajaran. Rokan Hulu: Universitas Pasir Pengaraian. 